\title{
JIM CROW, INDIAN STYLE: THE DISENFRANCHISEMENT OF NATIVE AMERICANS
}

\author{
Jeanette Wolfley*
}

\section{Introduction}

In 1965 Congress enacted the Voting Rights Act, which spurred the black voting rights movement in the South and set the stage for major changes in the national political system. The campaign for equal voting rights spread to Hispanic communities of the rural southwest and urban barrios.' Indians have taken the path developed by blacks and Hispanics to seek enforcement of the fifteenth amendment by challenging election schemes and systems devised by towns bordering reservations, counties, and school districts throughout the West and Southwest. ${ }^{2}$

Like black and Hispanic voters, Indians have faced intense, deep-seated resistance and racism from the majority community while attempting to gain and exercise the franchise. The Indians' struggle to participate in the democratic process has a unique and complex history which mirrors their long, cyclic relationship with the federal government. Indeed, the history of Indian disenfranchisement reflects a panoply of shifting majority attitudes, policies, and laws toward Indians.

This article examines the ongoing struggle of Indians to gain the right to vote and, thus, have a meaningful opportunity to fully participate in the political process. It will discuss historical and modern disenfranchisement and the continued progress toward the goal of political equality envisioned by the fifteenth amendment.

(C) 1990 Jeanette Wolfley

- General Counsel, Shoshone-Bannock Tribes; Former Director of the Voting Rights Project and Staff Attorney, Native American Rights Fund. J.D., 1982, University of New Mexico; B.A., 1979, University of Minnesota. I wish to thank Jacqueline Williams and Vicki Powers for their time and comments on previous drafts of this article.

1. See Gomez v. City of Watsonville, 852 F.2d 1186 (9th Cir. 1988); Campos v. City of Baytown, 840 F.2d 1240 (5th Cir. 1988).

2. See, e.g., Windy Boy v. County of Big Horn, 647 F. Supp, 1002 (D. Mont. 1986) (lawsuit by Crow and Northern Cheyenne against at-large elections in Montana); Buckanaga v. Sisseton Indep. School Dist., 804 F.2d 469 (8th Cir. 1985) (challenge by Sisseton-Wahpeton Sioux to at-large school district in South Dakota); Sanchez v. King, 550 F. Supp. 13 (D.N.M. 1982), aff'd, 459 U.S. 801 (1983) (Navajo and Pueblo voters' action against reapportionment plan of New Mexico). 


\section{Imposition of Naturalization and Citizenship}

In the past 200 years, federal Indian policy has been a product of tension between two conflicting responses to the "Indian problem" - separation and assimilation. One federal policy coerced Indians to adopt and integrate into the mainstream white majority, while another obstructed their participation in the growing American society. The struggle over Indian voting rights illustrates these two policies.

Naturalization and citizenship laws were major mechanisms to facilitate federal efforts to assimilate Indians, obtain Indian lands, and terminate tribal governments. From 1854 to 1924 , naturalization and citizenship were the primary devices used to induce assimilation. As this article will show, these federal efforts were not readily accepted by the majority society and Indians. ${ }^{3}$

The common objectives of the majoritys' views stemmed from the principles articulated by Chief Justice Marshall in his three landmark opinions, known as the Marshall Trilogy: Johnson $v$. M'Intosh, ${ }^{4}$ Cherokee Nation v. Georgia, ${ }^{5}$ and Worcester v. Georgia. ${ }^{6}$ These cases treated Indian tribes as distinct, independent

3. See, e.g., In re Heft, 197 U.S. 488, 499-502 (1905), overruled sub nom. United States v. Nice, 241 U.S. 591 (1916).

4. 21 U.S. (8 Wheat.) 543 (1823). In this decision, the Court held as invalid tribal conveyance of land to private individuals. The Court reasoned that Indians retained a right of occupancy extinguishable by discovering European sovereigns. The result was a recognition of a legal right of Indians in their lands valid against all parties save the federal government.

5. 30 U.S. (5 Pet.) 9 (1831). Cherokee Nation expanded the recognition of Indian sovereignty set forth in Johnson $v$. M'Intosh. Georgia attempted to impose its laws on the Cherokees in violation of treaty provisions. To stop such intrusions, the Cherokee filed suit in the Supreme Court under article III, section 2 of the United States Constitution-a section which gives the Supreme Court original jurisdiction in cases and controversies involving states and foreign nations. Id. at 7-14. The key issue before the Court was whether the Cherokees constituted a "foreign nation" in the Constitutional sense. Chief Justice Marshall determined that they did not. However, Marshall determined that the tribe was a state in the international sense; it was "a distinct political society separated from others, capable of managing its own affairs and governing itself." Id. at 16. Marshall noted that the tribe was "in a state of pupilage," and "their relations with the United States resembles that of a ward to his guardian." Id. at 17.

6. 31 U.S. (6 Pet.) 515,528 (1832). The following term, Justice Marshall addressed the unresolved issue of state jurisdiction over Indian tribes. Georgia attempted to prevent non-Indians from living on Cherokee lands without permission of the State's Governor. In a strongly-worded opinion, Marshall struck down the application of Georgia law to Cherokee lands, stating: "The Cherokee nation, then, is a distinct community, occupying its own territory, with boundaries accurately described, in which the laws of Georgia can have no force." Id. at 561. Marshall's opinion is the foundation of law excluding a states' law from Indian Country. 
political communities. As seen below, this treatment has since raised questions of dual citizenship, wardship, and competency. Naturalization

In Marshall's understanding, Indian tribes possessed a sovereignty as complete as that of any European nation. After forming political alliances through treaties with the United States, tribes surrendered their sovereignty but remained sovereigns in the sense the term has been used since the early nineteenth century. ${ }^{7}$ Prior to the General Allotment Act of $1887,{ }^{8}$ most Indians were considered members of separate political communities and not part of the state politic or the United States. ${ }^{9}$ The term "sovereign" is used to describe the status of tribal governments, and it is acknowledged by the United States Supreme Court as a fundamental of modern federal law. ${ }^{10}$

Despite the Marshall Trilogy, the settlers' demand for Indian lands increased rapidly and forced politicians to develop a policy of removal. West of the Mississippi River lay vast amounts of presumably unoccupied lands; by pushing Indians beyond the river settlers would possess the land.

The popularity of removal was so strong that the federal government embarked on a campaign of negotiating removal treaties even before President Andrew Jackson signed the Indian Removal Act of $1830 .{ }^{11}$ Removal was more than an assault on

7. Tribal sovereignty as recognized in Worcester is best described by Felix Cohen: The whole course of judicial decision on the nature of Indian tribal powers is marked by adherence to three fundamental principles: (1) An Indian tribe possess, in the first instance, all the powers of any sovereign state, (2) Conquest renders the tribe subject to legislative power of the United States, and, in substance, terminates the external powers of sovereignty of the tribe, e.g., its power to enter into treaties with foreign nations, but does not, by itself, affect the internal sovereignty of the tribe, i.e., its power of local self-government, (3) these powers are subject to qualification by treaties and by express legislation of Congress, but, save as thus expressly qualified, full powers of internal sovereignty are vested in the Indian tribes and in their duly constituted organs of government.

F. Cohen, Handboox of Federal Indian Law 123 (1942 ed.

8. See infra note 56 and accompanying text.

9. See Cherokee Nation v. Georgia, 30 U.S. (5 Pet.) 1 (1831); The Kansas Indians 72 U.S. (5 Wall.) 737 (1866); United States v. Kagama, 118 U.S. 375 (1886).

10. In modern times, the Supreme Court has held that tribal governments are "unique aggregations possessing attributes of sovereignty over both their members and their territory." See, e.g., United States v. Wheeler, 435 U.S. 313 (1978).

11. Ch. 148, 4 Stat. 411 (current version of $\S \S 7-8$ at 25 U.S.C. $\S 174$ (1988)). The Act authorized President Jackson to exchange territory west of the Mississippi River for the lands of eastern tribes. For further discussion, see F. CoHEN, HaNDBOOK OF FeDeral InduN LAW 78-92 (1982 ed.). 
Indians; many believed that the removal policy was the only means of saving Indians from extermination. Removal eventually served to promote assimilation, albeit assimilation by separation.

In conjunction with removal, the federal government created the reservation, a strategy which sought to change Indian tribes politically, socially, and economically. ${ }^{12}$ Instead of their traditional tribal leadership, most tribal members found themselves subject to the authority of white agents from the Bureau of Indian Affairs (BIA). However, many reformers saw the reservations as cultural failures; others as economic failures or obstacles to progress. For example, railroads were accelerating their demand for Indian lands and cattle ranchers made similar demands.

With the reservation policy clearly not working, reformers abandoned it and launched a triple assault on Indian sovereignty: the creation of a federal school system for Native Americans, ${ }^{13}$ the extension of federal laws to Indians, ${ }^{14}$ and the allotment of tribal lands. ${ }^{15}$

By splintering the reservations and distributing the land in allotments to individual Indians, the reformers hoped to destroy tribal economic power and assimilate Indians to European-American commercial values. It was intended that when tribal economic power was eliminated, tribal political power would also wane; the reformers would then grant United States citizenship to allotted Indians. Thus, federal supervision of Indians would become unnecessary. The reformers believed economic self-sufficiency, legal subjugation, and assimilation was the solution to the "Indian problem."

Most reformers agreed that assimilation was the ultimate solution, and a structured education, an allotment policy, and United States citizenship were the most effective ways to bring it about. Some reformers wanted assimilation immediately: railroads, oil companies, homesteaders and cattle ranchers demanded immediate placement of Indian children in schools, award of citizenship, and allotment of tribal land. Other re-

12. See ch. 85, 3 Stat. 516 (1819) (current version of $\S 1$ at 25 U.S.C. $\$ 271$ (1988)).

13. Education for Indians was provided by mission schools in the early days. Beginning in the late 1870s, off-reservation boarding schools were established. In the eyes of reformists, off-reservation boarding schools were the ideal method of assimilation because Indian youth were removed from their families. See Speclal Subcoma. on indun Education, A National Tragedy-A National Chullenge, S. Rep. No. 501, 91 st Cong., 1st Sess. 140-52 (1969).

14. See F. Prucha, American Indun Policy In Crisis 328-41 (1976).

15. See infra text accompanying notes $16-17,44-50, \&$ 57-60. 
formers insisted on a more gradual approach that emphasized citizenship and allotment only when an Indian was culturally prepared for both. Between 1880 and 1934, policy toward Indians vacillated between these extremes.

Congressional efforts to naturalize entire tribes generally fell short of their intended goal. For example, from 1839 to 1850 , the Stockbridge-Munsee, Brotherton, and Wyandot Indians were plagued with incessant congressional efforts to make them citizens. ${ }^{16}$ In other congressional attempts, citizenship was made dependent upon the acceptance of an allotment of land; the alternative to accepting an allotment was removal from native lands. ${ }^{17}$

Indians who were not granted citizenship by congressional action were barred from the naturalization process open to European immigrants; Indians were regarded as domestic subjects or nationals. ${ }^{18}$ This concept of Indian status was reiterated by United States Attorney General Caleb Cushing in 1856: ${ }^{19}$

The fact, therefore, that Indians are born in the country does not make them citizens of the United States. The simple truth is plain, that Indians are subjects of the United States, and therefore are not, in mere right of home-birth, citizens of the United States.

...

But they cannot become citizens by naturalization under existing general acts of Congress. Those acts apply to foreigners, subjects of another allegiance. The Indians are not foreigners, and they are in our allegiance, without being citizens of the United States. Moreover, those acts only apply to "white" men.

16. See Act of Mar. 3, 1839, ch. 83, 5 Stat. 349, 351 (Brotherton); Act of Mar. 3, 1843, ch. 101, $\$ 7,5$ Stat. 645, 647 (Stockbridge); Act of August 6, 1846, ch. 85, 9 Stat. 55 (Stockbridge); Treaty with the Senecas [and Others], Feb. 23, 1867, art. 13, 15 Stat. 513, 516 (tribal signatories included the Senecas, Shawnees, Quapaws, and Wyandots). Article 13 of the treaty with the Senecas prohibited tribal membership to Wyandots who had consented to United States citizenship under a prior treaty unless they were found "unfit for the responsibilities of citizenship." Id.

17. See Treaty with the Pottawatomie Indians, Feb. 27, 1867, United StatesPottawatomies, art. 6, 15 Stat. 531, 531-33; Treaty with the Sioux Indians, Apr. 29, 1868, United States-Sioux, art. 6, 15 Stat. 635, 637; Treaty with the Choctaws, Sept. 27, 1830, United States-Choctaws, arts. 14, 16, 7 Stat. 333, 335-36.

18. See In re Camille, 6 Fed. 256 (C. Or. 1880); In re Burton, 1 Alaska 111 (D. Alaska 1900). Camille is a prime example of the deep-seated racism held by many whites, and certainly by the judiciary, against nonwhite persons in the late 1800 s.

19. 7 Op. Att'y Gen. 746 (1856). 
-..

Indians, of course, can be made citizens of the United States only by some competent act of the General Government, either a treaty or an act of Congress. ${ }^{20}$

In the early citizenship case of Scott $v$. Sanford ${ }^{21}$ (the Dred Scott Case), the Supreme Court held that a black person could not become a citizen under the Constitution. ${ }^{22}$ The Supreme Court stated, in dictum, that Indians were not citizens, in the constitutional sense, but that Congress had the power to naturalize Indians. ${ }^{23}$ Thus, the Dred Scott Case effectively concluded that Indians who were unable to prove they were born under United States jurisdiction ${ }^{24}$ were precluded from registering to vote.

Although Congress did eventually naturalize all Indians, before the Reconstruction $\mathrm{Era}^{25}$ the general naturalization laws were restricted to European immigrants and did not include native-born Indians. ${ }^{26}$ In 1868 , section 1 of the fourteenth amendment defined citizenship as "all persons born or naturalized in the United States, and subject to the jurisdiction thereof, are citizens of the United States ...."27

20. Id. at 749-50.

21. 60 U.S. (19 How.) 393 (1857).

22. Id. at 403-04. This notorious decision was legislatively overridden by the Civil Rights Act of 1866, ch. 31, \& 1, 14 Stat. 27, 27.

23. Scott, 60 U.S. (19 How.) at 403-04.

24. See infra note 29 and accompanying text.

25. After the Civil War, the First Reconstruction Act of 1867 mandated that the Confederate States, in order to reenter the Union, had to adopt new constitutions guaranteeing male suffrage without regard to race. Act of Mar. 2, 1867, ch. 153, 14 Stat. 428. Subsequently, Congress adopted the fifteenth amendment in 1870 , which guarantees the right to vote irrespective of "race, color, or previous condition of servitude." U.S. Const. amend. XV, $\$ 1$.

26. See Act of Apr. 14, 1802, ch. 28, 2 Stat. 153. Indians born in Canada, Mexico, or other foreign countries did not become eligible for citizenship until the adoption of the Nationality Act of 1940 , ch. 876, $\$ 303,54$ Stat. 1137, 1140, superseded by Act of June 27, 1952, ch. 477, \&301, 66 Stat. 163, 235 (codified at 8 U.S.C. $\& 1401$ (1952)), because the Citizenship Act of 1924 referred only to "Indians born within the territorial limits of the United States." Act of June 2, 1924, ch. 233, 43 Stat. 253, 253. See Morrison v. California, 291 U.S. 82, 95 n.5 (1934)

27. U.S. Const. amend. XIV, 1 :

All persons born or naturalized in the United States, and subject to the jurisdiction thereof, are citizens of the United States and of the state wherein they reside. No state shall make or enforce any law which shall abridge the privileges or immunities of citizens of the United States' nor shall any state deprive any person of life, liberty, or property, without due process of law; nor deny to any person within its jurisdiction the equal protection of the laws. 
Following passage of the amendment, some erroneously thought Indians automatically qualified for United States citizenship because of the phrase "all persons," and because Indians were not explicitly excluded. This dispute prompted the Senate to instruct the Senate Judiciary Committee to inquire into the status of Indians under the amendment. ${ }^{28}$

In December, 1870 , the Senate Judiciary Committee reported that Indians who maintained their tribal relations were not citizens under the fourteenth amendment. Therefore, they could not be said to have been born under the complete jurisdiction of the United States. ${ }^{29}$ The Committee had the view that citizenship was incompatible with continued participation in tribal government or tribal property. That is, citizenship required affirmative consent to jurisdiction of the United States. The report stated:

To maintain that the United States intended, by a change of its fundamental law, which was not ratified by these tribes, and to which they were neither requested nor permitted to assent, to annual treaties then existing between the United States as one party, and the Indian tribes as the other parties respectively, would be to charge upon the United States repudiation of national obligations, repudiation doubly infamous from the fact that the parties whose claims were thus annulled are too weak to enforce their just rights, and were enjoying the voluntarily assumed guardianship and protection of this Government. ${ }^{30}$

One year later, an Oregon district court agreed with the Judiciary Committee and held that Indians born in tribal allegiance were not persons born in the United States and thus subject to its jurisdiction. ${ }^{31}$ The court stated:

To be a citizen of the United States by reason of his birth, a person must not only be born within its territorial limits, but he must also be born subject to its jurisdiction-that is, in its power and obedience. ... But the Indian tribes within the limits of the United States have always been held to be distinct

28. Cong. Globe, 41 st Cong., 2d Sess. 2479 (1870) (text of the resolution of inquiry).

29. Sen. Rep. No. 268, 41st Cong., 3d Sess. 1-11 (1870).

30. Id. at 11.

31. McKay v. Campbell, 16 F. Cas. 161 (D. Or. 1871) (No. 8840). 
and independent political communities, retaining the right of self-government, though subject to the protecting power of the United States. ${ }^{32}$

This position was sustained by a subsequent United States Supreme Court naturalization case, Elk $v$. Wilkins. ${ }^{33}$

Elk represents a torturous interpretation of state statutes and constitutional amendments in order to prevent Indians from voting. John Elk left his tribe and resided in Omaha, Nebraska. He attempted to exercise his right to vote in Nebraska. The Court, in upholding the denial of his right to vote, reasoned that he was not an American citizen because his intent to become a citizen required a positive and specific response from the United States before it could affect his status as a citizen. ${ }^{34}$

The Court further concluded that the fifteenth amendment did not apply to Elk, nor was he a United States citizen because he did not owe allegiance to the United States. ${ }^{35}$ A final reason for denying the right to Elk was that the United States had entered into treaties and enacted statutes (before and after the fourteenth amendment) naturalizing particular tribes and portions of tribes. ${ }^{36}$ Therefore, the federal government had other legislative means of naturalizing Indians.

The majority opinion chose to disregard that Elk had severed relations with his tribe. ${ }^{37}$ The Court construed section 1 of the fourteenth amendment as requiring a person deemed a citizen by birth to be subject to the ordinary jurisdiction of the United States at the time of birth. ${ }^{38}$ Since Elk was born to a tribal member who lived on tribal land, he was not a citizen by birth.

32. Id. at $165-66$.

33. 112 U.S. 94 (1884).

34. Elk, 112 U.S. at 109.

35. Id. at 99. The Court also relied on the fourteenth amendment phraseology, "Indians not taxed," to deny the franchise to Elk. Section 2 of the fourteenth amendment provides: "Representatives shall be apportioned among the several States according to their respective numbers, counting the whole numbers of persons in each state, excluding Indians not taxed." U.S. Const. amend. XIV, $\$ 2$ (emphasis added). A similar provision is found elsewhere in the Constitution. Id. art. I, $\$ 2, \mathrm{cl}$. 3. In 1926, when $\S 1$ was codified, the phrase "Indians not taxed" was deleted. See 8 U.S.C. $\S 1$ (1926).

36. Elk, 112 U.S. at 108-09.

37. Elk lived outside Indian Country within Nebraska and was subject to state and federal taxation.

38. Id. See also United States v. Osborn, 2 F. 58 (D. Or. 1880). For a study of the effects of tribal membership on citizenship, see Katzenmeyer v. United States, 225 F. 501, 523 (7th Cir. 1915). 
The Elk dissenting opinion by Judge Harlan is better reasoned. ${ }^{39}$ The dissent points out that the legislative history of the fourteenth amendment demonstrates the drafters understood those Indians, such as Elk, who were considered citizens pursuant to section 1.40 The dissent further argued that prior to the fourteenth amendment Congress had granted citizenship to many Indians who abandoned their tribal ties. ${ }^{41}$ The dissent also noted that the 1870 Senate Judiciary Committee report supported Indian citizenship under the fourteenth amendment, and that

the report closes with this significant language: "It is pertinent to say, in concluding this report, that treaty relations can properly exist with Indian tribes or Nations only, and that when the members of any Indian tribe are scattered, they are merged in the mass of our people and become equally subject to the jurisdiction of the United States." 42

To the advocates of immediate citizenship, the $E l k$ decision was an outrage. ${ }^{43}$ An English-speaking farmer and family man, Elk was acculturated to European-American society and was certainly deserving of citizenship. Something had to be done, and the advocates for gradual citizenship were pressured into merging the question of Indian citizenship with their drive for the allotment of tribal lands.

Following Elk, the legal status of Indians represented a state unknown to civil law: Indians were neither citizens nor aliens; they were not white under the naturalization laws, or slaves, or persons in a previous condition of servitude. ${ }^{44}$ Barring special acts, treaties, or a constitutional amendment, many Indians appeared to exist in a legal vacuum.

\section{Indian Citizenship}

Although John Elk was never naturalized, thousands of Indians were naturalized from the mid-1850s through the early

39. Elk, 112 U.S. at 112-19 (Harlan, J., dissenting).

40. Id. at 117-18. Significantly, the majority ignored the legislative history.

41. Id. at 115-16.

42. Id. at 119.

43. In an Asian-American naturalization case, United States v. Wong Kim Ark, 169 U.S. 649 (1898), the Supreme Court again found that Indians were not citizens. The Court excepted from its theory of citizenship by birth "members of Indian tribes of which owed immediate allegiance to their several tribes and were not part of the people of the United States... ." Id. at 662 (dictum).

44. The status of Indians was overshadowed at the end of the Civil War by the discussion and efforts for blacks to gain freedom, citizenship, and economic conditions equal to whites. 
1900 s. By accepting allotments and leaving the reservation or tribal society, Indians were rewarded with citizenship. By 1924, nearly two-thirds of all Indians were granted citizenship by treaties or special and general statutes. ${ }^{45}$

\section{Treaties and Special Acts}

The southeastern tribes were the first to receive citizenship through their treaties with the United States. ${ }^{46}$ In some treaties, citizenship was dependent on acceptance of an allotment of land in severalty. ${ }^{47}$ Indeed, in $E l k$, the Court identified twelve treaties, four statutes, four judicial opinions, and eight attorney general opinions that required "proof of fitness for civilization" before an Indian could obtain citizenship and the right to vote. ${ }^{48}$

Many tribes were naturalized by special statute. In the cases of the Stockbridge and Brotherton Tribes of Wisconsin, the tribes were dissolved and land distributed to the members. Once allotment was complete, the Indians became citizens. ${ }^{49}$ Citizenship was also premised on the requirements that Indians adopt the habits of "civilized life": learn to read and speak English. ${ }^{50}$ Another general act granted citizenship to Indian women who married white men..$^{51}$

In 1890 , as an enticement to members of the Five Civilized Tribes $^{52}$ to abandon their tribal relations, Congress passed the Indian Territory Naturalization Act. ${ }^{53}$ The Act provided

45. See D. McCool, Indian Votno 106 (1985).

46. Treaty with the Cherokees, July 8, 1817, United States-Cherokees, art. 8, 7 Stat. 156, 159; Treaty with the Cherokees, Feb. 27, 1819, United States-Cherokees, art. 2, 7 Stat. 195, 196; Treaty with the Choctaws, Sept. 27, 1830, United States-Choctaws, art. 14, 7 Stat. 333, 335. See F. CohEN, supra note 8, at $153 \mathrm{nn} .6-10$, for treaties conferring citizenship on tribes and individual Indians.

47. See Treaty with the Kickapoos, June 28, 1862, art. 3, 13 Stat. 623, 624; Treaty with the Senecas [and Others], Feb. 23, 1867, art. 13, 15 Stat. 513, 516 (treaty between the United States and the Senecas, Shawnees, Quapaws, Wyandots and others).

48. $E / k, 112$ U.S. at 100 .

49. See Act of Mar. 3, 1839, ch. 83, 5 Stat. 349, 351 (Brotherton); Act of Mar. 3, 1843, ch. 101, § 7, 5 Stat. 645, 647 (Stockbridge).

50. Act of Mar. 3, 1865, $\$ 4,13$ Stat. 541, 562. See Oakes v. United States, 172 F. 305 (8th Cir. 1909).

51. Act of Aug. 9, 1888, ch. 818, 25 Stat. 392.

52. The Seminole, Choctaw, Chickasaw, Cherokee, and Creek Nations.

53. Act of May 2, 1890, \& 43, 26 Stat. 81, 99-100. The Five Civilized Tribes opposed the grant of federal citizenship to their people because they feared it would terminate their tribal government. See S. Musc. Doc. No. 7, 45th Cong., 2d Sess. (Dec. 1877) (vol. I). Significantly, the Five Civilized Tribes were excluded from the General Allotment Act of 1887, $\$ 6,8,24$ Stat. 388, 390-91. 
[t]hat any member of any Indian tribe or nation residing in the Indian Territory may apply to the United States court therein to become a citizen of the United States, and such court shall have jurisdiction thereof and shall hear and determine such application as provided ... [ [t]hat the Indians who become citizens of the United States under provisions of this Act do not forfeit or lose any rights or privileges they enjoy or are entitled to as members of the tribe or nation to which they belong. ${ }^{54}$

The Act is similar to statutes enacted for specific tribes. ${ }^{55}$ Also, more than any other federal legislation, it implies that Indians hold dual citizenship. However, it also reaffirms the potential incompatibility between tribal membership and United States citizenship.

\section{The Allotment Period}

In 1887 , Congress passed the most disastrous Indian legislation in United States history: the General Allotment Act of 1887 (GAA). ${ }^{56}$ The GAA had dual goals of opening Indian lands for white settlement ${ }^{37}$ and assimilating Indians into mainstream society. ${ }^{58}$

Assimilation was accomplished by imposing citizenship upon two classes of Indians: (1) those to whom allotments were made by the GAA, or any law or treaty, and (2) those who voluntarily lived apart from their tribes and "adopted the habits of civilized life." 59 Under the first instance, citizenship was automatic at the

54. Act of May 2, 1890, 843,26 Stat. 81, 99-100.

55. See, e.g., Act of July 15, 1870, 10, 16 Stat. 335, 361-63. Under this act, a Minnesota Winnebago could apply to the federal district court for citizenship. See also Act of Mar. 3, 1873, § 3, 17 Stat. 631, 632.

56. Ch. 199, 24 Stat. 388 (codified at 25 U.S.C. $\$ \$ 331-34,339,341-42,348$ (1982)) [hereinafter GAA]. This legislation is also known as Dawes Severalty Act or the Dawes Act.

57. "[T] of land-hungry western settlers." History of the Allotment Policy: Hearings on H.R. 7902 Before the House Comm. on Indian Affairs, 23d Cong., 2d Sess. 9 (1934) (statement of D. Otis), quoted in D. Getches, D. Rosenfelt \& C. Winkinson, Federal Indian LAW 71 (1979)).

58. Representative Skinner, House sponsor of the GAA, said that "tribal relations must be broken up" and the "example of the white people" would provide a model for the Indians. 18 CoNo. REC. 190-91 (1886).

59. GAA, ch. $119, \S 6,24$ Stat. 388, 390. Section 6 provided:

Every Indian born within the territorial limits of the United States, to

whom allotments shall have been made under the provisions of this act, 
end of the twenty-five year period in which the allotment was held in trust by the Secretary of Interior. However, some tribes had their period of trust status extended by legislation or executive order, so it became difficult to determine who was a United States citizen and who was not. This allotment requirement actually meant that citizenship, long recognized as a personal right of an individual, was really a function of the status of the real estate the Indian might possess.

Citizenship increased rapidly after the passage of the GAA. By 1890 , citizenship had been extended to 5,307 Indian allottees, and by 1900 , to $53,168 .{ }^{60}$ In 1901 , Congress awarded citizenship to another 101,506 Indians in Indian Territory, and by 1905 more than half of all Indians had become citizens. ${ }^{61}$ President Theodore Roosevelt aptly described the GAA as "a mighty pulverizing engine to break up the mass." 62

During this allotment period (1887-1901), among many Indians the recognition of United States citizenship became a ceremonial event: It symbolized the Indian casting away traditions and customs and assuming the beliefs and values of the majority society. One citizenship ceremony involved a man "shooting his last arrow" and taking hold of the handles of a plow to demonstrate his intent to become an American citizen. ${ }^{63}$ Another ritual involved an Indian woman accepting a workbag and purse to hold money earned from labor and "wisely kept." 64

Interest in further altering the trust status of Indian land continued. In 1906, Congress amended the GAA by enacting the Burke Act. ${ }^{65}$ Under the Burke Act, the twenty-five year trust period was eliminated and an Indian became a citizen upon the issuance of a fee patent. Conveyance of the fee patent was made after the Commission of Indian Affairs determined an allottee

or under any law or treaty, ... is hereby declared to be a citizen of the United States and entitled to all the rights, privileges, and immunities of such citizen.

GAA, \$ 6 .

60. J. Olson \& R. Whson, Native Americans in the Twentieth Century 73 (1984) [hereinafter Ozson \& WISON].

61. Id.

62. 35 Cono. REc, 90 (1901) (message by President Theodore Roosevelt).

63. V. Delorla, JR., Of Utmost Good Faith 142-43 (1971).

64. Id. at 143.

65. Act of May 8, 1906, ch. 2348, 34 Stat. 182 (codified at 25 U.S.C. $\$ 349$ (1988)). The Act was named after its sponsor, Congressman Charles Burke of South Dakota. 
was "competent and capable of managing his or her affairs. ..."66 Again, the granting of citizenship was made dependent on severance of tribal ties. ${ }^{67}$

\section{The Post-Allotment Period}

Prior to World War I, Woodrow Wilson's Secretary of Interior, Franklin K. Lane, identified the political potential of the Indian voter, particularly in the Dakotas, Arizona, New Mexico, Montana, Oklahoma, and other states with relatively large numbers of Indians. ${ }^{68}$ Secretary Lane urged the Democratic Party to seek to register Indian voters for the 1916 national election. Most whites in the western states were, however, quite hostile to the idea of Indians as voters, even though Indians would have been participating only in federal elections. ${ }^{6}$ In addition, both the Harding and Coolidge Administrations were cognizant of the political potential of the Indian voter and moved toward increasing Indian participation in the political decision-making process by seeking Indian involvement in the Republican Party. ${ }^{70}$

Meanwhile, during World War I Congress had again attempted to resolve the issue of Indian citizenship. After the United States entered the war, thousands of Indians volunteered for the armed forces and for support work in the states. Ironically, these volunteers included individuals whose tribes had been fighting the United States Army as recently as thirty-five years earlier. ${ }^{11}$ As a result of the Indian response, it became apparent to the federal government that it would finally have to respond to the ambiguity of the legal status of Indians. ${ }^{72}$ In

66. 25 U.S.C. $\$ 349$ (1988).

67. See United States v. Debell, 227 F. 760 (D.S.D. 1915).

68. See F. Svensson, The Ethinics in American Polimics: American Induns 2425 (1973).

69. Id. at 25 .

70. Id.

71. Id. The Iroquois League, in an effort to reassert its autonomy and independence as a nation, formally declared war on Germany in 1917, separately from the United States and claimed status as one of the Allied Nations. Additionally, during the citizenship debates of the early 1920s, the Iroquois protected any attempts to grant them citizenship and declared that they would not accept citizenship if Congress granted it in the future.

72. In 1918, it was reported that the Indian population was 336,000 . Though less than 10\% were military age, more than 7,000 served in the armed forces. Also at that time only $30 \%$ of all Indians could read and write English and less than half were citizens. Peterson, Native American Political Participation, Annuls, May 1957, at 116, 123. 
1919, Congress declared that all Indians who had served in the armed forces and received honorable discharges would be granted American citizenship upon application. ${ }^{73}$

Yet again, the citizenship question was caught up in a conflict of responses among the majority society. Some favored citizenship on moral grounds, while others viewed citizenship as the final step to integrating Indians into the main society. Congressmen such as Edgard Howard of Nebraska and Gale Stalker of New York, were interested in ending the trust status of Indian lands and advocated blanket immediate citizenship. ${ }^{74}$ Stalker and Howard introduced citizenship bills in $1923^{75}$ which encountered immediate hostility from factions who favored gradual assimilation and preservation of Indian lands and Indians who wanted to retain their tribal status. ${ }^{76}$

The Indian Citizenship Act of 1924

Out of these conflicting points of view came compromise legislation. In 1924, Congressman Homer P. Snyder of New York introduced House Resolution 6355, authorizing the Secretary of the Interior to grant citizenship to all Indians who requested it, if they were "individually prepared" for the responsibilities. ${ }^{77}$ In addition, the Senate Committee on Indian Affairs proposed a blanket immediate citizenship law, ${ }^{78}$ which was opposed by full-blood Indians and whites who were skeptical about rapid assimilation. Finally, out of Congress emerged the Indian Citizenship Act, ${ }^{79}$ which states

[t]hat all non-citizen Indians born within the territorial limits of the United States be, and they are hereby, declared to be citizens of the United States: Provided that the granting of such citizenship shall not in any manner impair or otherwise affect the right of an Indian to tribal or other property. ${ }^{80}$

73. See Act of Nov. 6, 1919, ch. 95, 41 Stat. 350.

74. Olson \& WILson, supra note 60 , at 84 .

75. Id.

76. Id. at 85 .

77. Id.

78. Id.

79. Act of June 2, 1924, ch. 233, 43 Stat. 253. The Act's drafter was Charles B. Curtis, a Kaw Indian from Oklahoma, who served in the United States House of Representatives (1893-1906), and the United States Senate (1907-13; 1913-1929). Curtis served as U.S. vice president under Herbert Hoover from 1929-1933.

80. Id. The substance of this Act was incorporated into the Nationality Act of Oct. 14,1949 , ch. $876, \S 201,54$ Stat. 1137,1138 (formerly codified at 8 U.S.C. $\S 601$ (1940)). It was superseded in 1952 by the Act of June 27, 1952, ch. 477, $\$ 301,66$ Stat. 163,235 (codified as amended at 8 U.S.C. $\$ 1401$ (1952)). 
The Indian Citizenship Act effectively ended the relationship between citizenship and tribal affiliation or federal protection. ${ }^{81}$

The question of citizenship is a complex one for Indians. Many Indians either had no interest in it or else actively sought to reject it. Some have challenged citizenship by refusing to vote in federal and state elections or denying their United States citizenship and strongly asserting tribal sovereignty. Also, tribes have issued tribal passports in place of United States passports. ${ }^{82}$

\section{The Justification by States in Denying Indians the Franchise}

An important premise flowing from the United States Constitution is that no one is granted the right to vote. Rather, the fifteenth amendment states that no citizen's right to vote shall be "denied or abridged by the United States or any state on account of race, color, or previous condition of servitude." second implication of the Constitution is that franchise is almost entirely a state matter; that is, states shall prescribe "the times, places and manner" of holding elections. ${ }^{84}$ Thus, states had the control over whether Indians could exercise their franchise.

Although Indians were granted United States citizenship in 1924, state doubts were not appeased. Most states continued to refuse to recognize Indians as citizens of the state in which they resided. Other states' officials devised laws to limit Indians' access to the ballot box. The unwillingness of states to allow Indians to vote was no surprise given the history of conflict and antagonism between Indian tribes and states. The often-quoted language of the Supreme Court in 1886 summed up the tribalstate political relationship: "They [tribes] owe no allegiance to the States and receive from them no protection. Because of the local ill feeling, the people of the United States where they are found are often their deadliest enemies." 85

81. Opponents of Indian rights continue to question the dual status of Indians. See infra notes 83-163 and accompanying text. The courts, however, have held the Act neither affected the trust relationship nor conditioned it upon the severance of tribal ties. See United States v. Wright, 53 F.2d 300, 306 (4th Cir. 1931), cert. denied, 285 U.S. (1932); United States v. Nice, 241 U.S. 591 (1916); Bowling v. United States, 233 U.S. 528 (1914); Hallowell v. United States, 221 U.S. 317 (1911).

82. See $\mathbf{F}$. Svensson, supra note 68 , at 26 . Tribal sovereignty and how some Indians regard the state-tribal relationship inhibits full participation in state politics. Some Indians contend that their voting in state elections would be an acknowledgement of state jurisdiction over Indian reservations. See U.S. Como'n on Crvil Rights, NAtTVE american Partictpation in South Daxota's Polmtical System 19-21 (1981).

83. U.S. Const. amend. XV, \& 1.

84. U.S. Const. art. $1, \S 4$.

85. United States v. Kagama, 118 U.S. 375, 384 (1886). 
This hostility is evident still today. As noted in a recent New Mexico Indian voting rights case: "We note an abiding sentiment among the Indians of New Mexico that the state is an enemy of the tribes. In states with a significant number of Indians, there are disputes between tribal and state governments as to their respective spheres of authority. New Mexico is no exception." 86

States have five basic arguments in justifying the denial of voting rights to Indians: (1) failure to sever tribal ties makes Indians ineligible; (2) "Indians not taxed"; (3) Indians are under guardianship; (4) reservation Indians are not residents; and (5) tribal sovereignty precludes participation in state and local governments. ${ }^{87}$

\section{Failure To Sever Tribal Ties}

Abandonment of traditional Indian culture was once a prerequisite for participation in some state politics. The Minnesota Constitution once granted citizenship only to those Indians who had "adopted the language, customs and habits of civilization." "8s South Dakota also prohibited Indians from voting or holding office "while maintaining tribal relations." 89 The constitutions of Idaho and North Dakota contained similar language. ${ }^{00}$

In 1920, the votes of Indians in North Dakota were challenged by opponents. In Swift $v$. Leach, ${ }^{91}$ the North Dakata Supreme Court considered whether 273 Indians of the Standing Rock Sioux Tribe were eligible to vote under article 5, section 121 of the North Dakota Constitution..$^{22}$ Section 121 provided that:

86. Sanchez v. King, No. 82-0067-M, 2-0084-C, 82-0180-C, 82-0219-JB, 82-0246JB, slip op. at 27 (D.N.M. Aug. 8, 1984) (Findings of Fact, Conclusions of Law).

87. These justifications have been categorized as "constitutional ambiguity, political and economic factors, and cultural and racial discrimination." D. MCCOoL, INDLAN Voting 106 (1985). See also M. Price, Law and the American Indian 229-37 (1973). Price analyzed five arguments: severance of tribal relations, lack of state power over Indian conduct, fear of political control shifting of Indian majorities, guardianship, and residency.

88. MinN. Const. art. VII, $\$ 1, \mathrm{cl} .4$ (1857, repealed 1960).

89. S.D. Codmied Laws ANN. $\$ 92$ (1929). This law requiring severance of tribal ties remained on the books until 1951.

90. Idaho Const. art. VI, $\$ 3$ (1890, repealed 1950); N.D. Const. art. V, $\$ 121$ (1889, repealed 1922).

91. 45 N.D. 437,178 N.W. 437 (1920). Swift has also been rejected in favor of the proposition that federal guardianship of Indians disqualifies Indians as electors. See Porter v. Hall, 34 Ariz. 308, 271 P. 411, 412 (1928).

92. Swift, 178 N.W. at 438. 
Every male person of the age of twenty-one years or upwards, belonging to either of the following classes, who shall have resided in the state one year and in the county six months, and in the precinct ninety days next preceding election, shall be a qualified elector at such election:

....

... Civilized persons of Indian descent who shall have severed their tribal relations two years next preceding such election..$^{93}$

In determining whether the Indians were eligible to vote, the court reviewed testimony of numerous witnesses (superintendents of the local Indian agency, a county judge, and other county officials) who testified that the "trust patent" Indians had severed tribal ties. ${ }^{94}$ One superintendent of the Fort Yates Agency testified on behalf of the Indian voters by stating:

[T]he Indians have ceased to live in bands under a chief; . . .their educational qualifications compare favorably with white people; they marry the same as white people; have fixed abodes, they live as white people; they are competent to handle their own affairs, and their knowledge of English is as good as the average white man; they have severed their tribal relations and adopted the mode of civilized life and are well qualified to become citizens of this state. ${ }^{95}$

In sum, the testimony emphasized that the Sioux voters were loyal to the majority government, rather than their tribe.

The county argued that (1) the Indians were not civilized, (2) they could not sever their tribal ties without federal consent, and (3) they were under guardianship and, thus, ineligible to vote. 96 In rejecting these arguments, the court found that the Indians were electors under section 21 of the state constitution because they had "adopted and observed the habits and mode of life of civilized persons." 97

93. N.D. Const. art. V, § 121 (1889, amended 1898 \& 1920, repealed 1922$).$

94. Swift, 178 N.W. at 438-39. The Indians were referred to as "trust patent" Indians because they received allotments of land under the Burke Act but had not yet received fee titles.

95. Id., 178 N.W. at 439.

96. Id., $178 \mathrm{~N} . \mathrm{W}$. at $440-41$.

97. Id., $178 \mathrm{~N} . \mathrm{W}$. at 443. A similar inquiry regarding abandonment of tribal relation occurred in Osborn, in which the defendant was charged with selling liquor to 


\section{"Indians Not Taxed"}

The phrase "Indians not taxed" was frequently used in state constitutions and statutes to exclude Indians from voting, and is found in the U.S. Constitution. ${ }^{98}$ It has been utilized as an economic argument that Indians should not be permitted to vote or participate in revenue decisions, i.e., bond elections, because they do not pay taxes. ${ }^{99}$ Additionally, some states have maintained that if the state government has no taxing power over an Indian reservation, then Indians should not be able to participate in the election of state officials.

The 1917 decision of the Minnesota Supreme Court in Opsahl v. Johnson ${ }^{100}$ typifies these views. In Opsahl, the court denied members of the Red Lake Chippewa Tribe the right to participate in county elections because the Indians had not "yielded obedience and submission to [Minnesota] laws."101

The court reasoned that Minnesota Indians were not subject to taxation as were other state residents. ${ }^{102}$ Therefore, the court concluded, it would be inconsistent with the state constitution to allow Indians the right to elect representatives. ${ }^{103}$ The court stated:

It cannot for a moment be considered that the Framers of the Constitution intended to grant the right of suffrage to persons who were under no obligation to obey the laws enacted as a result of such grant. Or, in other words, that those who do not come within the operations of the laws of the state, nevertheless shall have power to make and impose laws upon

an Indian. The purchaser-Indian was declared to be under federal supervision even though he had not lived among his Warm Springs Tribe for fifteen years. The federal court found that "an Indian cannot make himself a citizen of the United States without the consent and cooperation of the government." United States v. Osborn, 2 F. 58, 61 (D. Or. 1880).

98. U.S. Const. art. 1, $\$ 2$; id. amend. XIV, $\$ 2$.

99. Today, Indians pay a variety of taxes-federal, state and tribal. Indians living on certain Indian reservations also have tax exemptions not generally applicable to nonIndians.

100. 138 Minn. 42, 163 N.W. 988 (1917).

101. Id., 163 N.W. at 991 .

102. Quoting the state, the court declared, "The tribal Indian contributes nothing to the state. His property is not subject to taxation, or to the process of its courts. He bears none of the burdens of civilization, and performs none of the duties of the citizens." Id., 163 N.W. at 990.

103. Id. 
others. The idea is repugnant to our form of government. No one should participate in the making of laws he need not obey. ${ }^{104}$

In 1940, five states (Idaho, Maine, Mississippi, New Mexico, and Washington) still prohibited "Indians not taxed" from voting, ${ }^{105}$ even though they granted the franchise to whites who were not taxed. These states simply did not want Indians to participate in revenue decisions that they determined imposed financial burdens on non-Indians only.

On January 26, 1938, the Department of the Interior issued an opinion on the denial of the franchise to Indians. ${ }^{106}$ The solicitor concluded:

I am of the opinion that the Fifteenth Amendment clearly prohibits any denial of the right to vote to Indians under circumstances in which non-Indians would be permitted to vote. The laws of Idaho, New Mexico and Washington which would exclude Indians not taxed from voting, in effect exclude citizens of one race from voting on grounds which are not applied to citizens of other races. For this reason, such laws are unconstitutional under the Fifteenth Amendment. ${ }^{107}$

Eventually, four of the five states permitted Indians to vote regardless of taxation. New Mexico, however, persisted in its efforts to disenfranchise Indians based on the taxation issue.

In 1948, Miguel Trujillo, from Isleta Pueblo in New Mexico, was prohibited from voting because he did not have to pay state taxes on his property. Trujillo filed suit in federal court challenging the phrase "Indians not taxed" in the New Mexico Constitution. ${ }^{108}$ The district court found the prohibition in the New Mexico Constitution constituted a violation of the fourteenth and fifteenth amendments. ${ }^{109}$ Judge Phillips stated, for the court:

Any other citizen, regardless of race, in the State of New Mexico who has not paid one cent of tax of any

104. Id.

105. IDAho Const. art. VI, $\S 3$ (1890, amended 1950); N.M. Const. art. XII, $\S 1$;

WASH. Const. art. VI, § 1; Miss. Const. art. 12, \$241 (1890, amended 1968).

106. Op. Solic. Interior Dep't, M29,596 (Jan. 26, 1938).

107. Id.

108. Trujillo v. Garley, No. 1353 (D.N.M. Aug. 11, 1948) (three judge court).

109. Id., slip op. at 7 . 
kind or character, if he possesses the other qualifications, may vote. An Indian, and only an Indian, in order to meet the qualifications to vote, must have paid a tax. How you can escape the conclusion that makes a requirement with respect to an Indian as a qualification to exercise the elective franchise and does not make that requirement with respect to the member of any race is beyond me. I just feel like the conclusion is inescapable. ${ }^{110}$

The cry of "representation without taxation" echoed again in the 1970s in New Mexico and Arizona. ${ }^{11}$ The courts, however, failed to validate the arguments of opponents to Indian voters. In 1973, the Arizona Supreme Court held that an Indian may be elected to a county position even though he was immune from county and state taxation. ${ }^{112}$ Similarly, the New Mexico Supreme Court ruled that Indians may vote on a school board issue even though they were not taxed for repayment of a bond. ${ }^{113}$

\section{Indians Under Guardianship}

A third means employed by states to deny Indians the right to vote was the claim that Indians were under guardianship and, therefore, ineligible to participate in elections. For example, according to the Arizona Constitution, "No person under guardianship, non compos mentis, or insane, shall be qualified to vote at any election . . . unless restored to civil rights." 114

In 1928, two members of the Pima Tribe of the Gila River Reservation attempted to register to vote in the first presidential election held after the Indian Citizenship Act of 1924 had granted them citizenship. Robert Porter and Rudolph Johnson, the tribal members denied registration, sought a writ of mandamus directing the county registrar to enter their names on the county register. ${ }^{115}$

The Arizona Supreme Court considered two questions. First, was the Gila River Reservation within the boundaries of Arizona? If so, Porter and Johnson would be considered residents

110. Id., slip op. at 7-8.

111. Shirley v. Superior Court, 109 Ariz. 510, 513 P.2d 939 (1973), cert. denied, 415 U.S. 919 (1974); Prince v. Board of Educ., 88 N.M. 548, 543 P.2d 1176 (1975).

112. Shirley, 513 P.2d at $939-40$.

113. Prince, 543 P.2d at 1176.

114. Anu. Const. art. VII, $\S 2$.

115. Porter v. Hall, 34 Ariz. 308, 271 P. 411,412 (1928). 
of Arizona. ${ }^{116}$ Second, were Indians "under guardianship" within the meaning of the Arizona Constitution?117

The court determined that Indians residing on reservations located within state boundaries were residents of Arizona. ${ }^{118}$ The court, however, concluded that Mr. Porter and Mr. Johnson, as wards of the federal government, were "under guardianship" within the meaning of the Arizona Constitution and, thus, not qualified to vote. ${ }^{119}$

In reaching its decision, the court relied heavily on the language of Chief Justice Marshall's opinion in Cherokee Nation $v$. Georgia: "Their [tribes] relation to the United States resembles that of a ward to his guardian."120 Numerous cases following Cherokee Nation are quoted with similar wording. ${ }^{121}$

In addition, the court refused to follow the earlier North Dakota case, Swift $v$. Leach, which rejected the "under guardianship" argument.122 The court added that when the "Indian wards" are "released from their guardianship" by the United States, the state will entitle them "to vote on the same terms as other citizens." 123

In a strongly-worded dissent, Chief Justice Ross pointed out that Indians are citizens by virtue of the Indian Citizenship Act of 1924. ${ }^{124}$ More significantly, he argued that Chief Justice Marshall, in Cherokee Nation, stated that the Indians' relation to the United States resembled that of a ward to a guardian: "It is not a guardianship . . . but 'resembles' a guardianship." 125 The guardianship referred to in the Arizona Constitution is a court-determined legal guardianship, Ross argued; therefore, it has no application to Indians. ${ }^{126}$

The reasoning of Chief Justice Ross is correct. The federalIndian trust relationship created in Cherokee Nation is unique

116. Id., 271 P. at 413.

117. Id.

118. Id., 271 P. at 415.

119. Id. $271 \mathrm{P}$. at 418.

120. Id., 271 P. at 417 (citing Cherokee Nation v. Georgia, 30 U.S. (5 Pet.) 1, 16 (1882).

121. Id., 271 P. at 417-18. E.g., United States v. Kagama, 118 U.S. 375,379 (1886) ("These Indians are wards of the nation. They are communities dependent on the United States."); see also Jones v. Meechan, 175 U.S. 1 (1899); Williams v. Johnson, 239 U.S. 414 (1915).

122. Porter, 271 P. at $418-19$ (citing Swift v. Leach, 45 N.D. 437,178 N.W. 437 , (1920)).

123. Id., 271 P. at 419.

124. Id.

125. Id. (quoting Cherokee Nation v. Georgia, 30 U.S. (5 Pet.) 1, 16 (1882)).

126. Id. 
and differs greatly from common law guardianship. ${ }^{127}$ The federal obligation toward Indians is expressed in treaties, statutes, agreements, executive orders, and administrative regulations. These obligations define the required standard of conduct for federal officials and Congress. In matters not subject to federal restrictions or responsibilities, Indians are as independent and as competent as other persons. Moreover, common law guardianships are supervised by state courts and terminate if and when the disability (mental incompetency, infancy) ends.

For twenty years, Porter $v$. Hall stood unchallenged. Upon returning home from fighting during World War II, many Indian veterans pushed for the right to vote. ${ }^{128}$ In 1948, two MohaveApache Indians attempted to register to vote but were turned away. They filed suit and the Arizona Supreme Court again had the opportunity to interpret the meaning of the clause "persons under guardianship."129

This time the Arizona Supreme Court took a different view. The court distinguished between common law guardianship and the guardianship described in Cherokee Nation v. Georgia. Citing Chief Justice Ross' dissent in Porter, the court held the guardianship clause in the Arizona Constitution was "intended to mean a judicially established guardianship ... . [and] has no application to the plaintiff[s] or to the federal status of Indians in Arizona as a class." 130 The court noted that Porter was a "tortions [sic] construction by the [state] judicial branch of the simple phrase 'under guardianship', to accomplish a purpose never designed by the legislature." "131 Thus, Porter was expressly overruled by Harris. ${ }^{132}$

\section{Indians As Non-Residents}

An equally tenuous fourth argument used to bar Indians from voting was a residence clause in certain state election statutes.

127. For a further discussion, see Houghton, The Legal Status of Indian Suffrage in the United States, 19 CALIF. L. Rzv. 507, 508, 511-12 (1931).

128. Approximately 25,000 Indians served in the armed forces during World War II. Peterson, supra note 74, at 123. In 1947, the President's Committee on Civil Rights declared the state prohibitions, such as those in Porter, discriminatory and explained that "[P]rotest against these legal bans on Indian suffrage in the Southwest have gained force with the return of Indian veterans to those states." REPORT OF THE Presmens's Comansion on Civil Rights 40 (1947).

129. Harrison v. Laveen, 67 Ariz. 337, 196 P.2d 456 (1948).

130. Id., 196 P.2d at 463.

131. Id., 196 P.2d at 461 .

132. Id., 196 P.2d at 463. 
In the 1950s and 1960s, the New Mexico and Utah courts wrestled with the issue about whether a person living on a reservation located within a state was a resident of that state.

In a 1956 case, Allen $v$. Merrell, ${ }^{133}$ the Supreme Court of Utah interpreted the state's election statute, which provided: "Any person living upon any Indian or military reservation shall not be deemed a resident of Utah within the meaning of this chapter, unless such person had acquired a residence in some county in Utah prior to taking up his residence upon such Indian or military reservation." 134 The court concluded that the statute was not a denial of the right to vote on the basis of race in violation of the equal protection clause. ${ }^{135}$ The court justified the residence requirement on three grounds: (1) tribal sovereignty, (2) federal government control of the reservation, and (3) Indians were not acquainted with the processes of government. ${ }^{136}$ The court further reasoned that Indians do not speak English, do not pay taxes, and are not fully under state jurisdiction, and therefore, the residency statute was justified. ${ }^{137}$ The Allen opinion also expressed a fear that the Indian population might outnumber the white voters, and it would be unfair to let them control state politics because they had "an extremely limited interest in its functions and very little responsibility in providing the financial support thereof."138

Allen was appealed to the United States Supreme Court, which vacated the decision and remanded it for rehearing. ${ }^{139}$ In the interim, the Utah legislature repealed the disenfranchisement statute. ${ }^{140}$

In 1962, the New Mexico Supreme Court had occasion to consider the issue of residency involving Indians in Montoya $v$. Bolack. ${ }^{141}$ The Indians' right to vote was challenged in vain by the unsuccessful candidate for Lieutenant Governor of New Mexico, who would have been the victor had the Navajo votes in San Juan and McKinley counties been thrown out.

Montoya contended that Indian reservations were not part of the state and, therefore, not a "residence" for voting pur-

133. 6 Utah 2d 32, 305 P.2d 490 (1956).

134. UtAh CODE ANN. \& 20-2-14 (11) (1953).

135. Allen, 305 P.2d at 495.

136. Id., 305 P.2d at 492.

137. Id., 305 P.2d at 495.

138. Id.

139. 353 U.S. 932 (1957). For further discussion of Allen, see Note, Denial of Voting Rights to Reservation Indians, 5 UTAH L. Rev. 247 (1956).

140. Act of Feb. 14, 1957, ch. 38, 1957 Utah Laws 89-90.

141. 70 N.M. 196, 372 P.2d 387 (1962). 
poses. ${ }^{142}$ Moreover, he argued problems could arise with polling places located on reservations: If there was a violation of the state election code, nothing could be done because the state did not have jurisdiction on the reservation. ${ }^{143}$

In upholding the Indians' right to vote, the court recognized that lack of state jurisdiction over Indians "is of serious moment, but so is the refusal of the right to vote." 144

\section{Tribal Sovereignty}

During the nineteenth century, opponents of Indian citizenship took the position that maintaining tribal ties was incompatible with citizenship, being 'civilized', and voting in state elections. ${ }^{145}$ This argument was discussed and disposed of in early cases. ${ }^{146}$ However, in recent voting rights litigation, states and local officials have resurrected the argument to abridge and diminish the voting rights of Indians.

The argument used by states is that Indians do not care or wish to participate in state or county affairs, and instead rely on the tribal and federal government for certain services and political participation. Therefore, states maintain, tribal sovereignty, rather than discrimination, explains the state government's treatment of Indians and also the diminished participation of Indians in state and local political activities. ${ }^{147}$

The tribal sovereignty/reduced participation position has been rejected by the federal government. When Congress extended the protections of the Voting Rights Act of 1975, 148 it considered the tribal sovereignty argument. Congress found that discrimination against Indians and other language minorities by the states "was substantial" and that "[l]anguage minority citizens, like blacks throughout the South, must overcome the effects of discrimination as well as efforts to minimize the impact of their political participation. ${ }^{149}$ Based upon an "extensive evidentiary record" demonstrating the prevalence of voting discrimination

142. Id., 372 P.2d at 388 .

143. Id., 372 P.2d at 394.

144. Id.

145. See supra notes 88-97 and accompanying text.

146. For example, see Swift v. Leech, 45 N.D. 437, 178 N.W. 439 (1920).

147. See Defendant's Brief on Remand, Buckanaga v. Sisseton School Indep. Dist., No. 84-1025 (1988); Defendants' Post-Trial Brief, Windy Boy v. County of Big Horn, 647 F. Supp. 1002 (D. Mont. 1986) (No. CV83-225 BLG-ER).

148. Act of Aug. 6, 1975, Pub. L. No. 94-73, 89 Stat. 400, 402; S. ReP. No. 295, 94th Cong., 1st Sess. 38 (1975).

149. S. ReP. No. 295, 94th Cong., 1st Sess. 24, 38 (1975). 
against Indians, ${ }^{150}$ Congress extended the special pre-clearance provisions of section 5 to include language minorities. It also required a number of jurisdictions with Indian populations to provide bilingual election procedures. ${ }^{151}$ Congressional action in extending the Voting Rights Act to Indians belies state arguments that diminished political participation of Indians is unrelated to discrimination.

Congress again disposed of the tribal sovereignty claim when it amended section 2 of the Voting Rights Act of $1982 .{ }^{152}$ Section 2 expressly applies to Indians; Congress stated that it was adopting a nationwide standard for vote dilution. ${ }^{153}$ Thus, state arguments that Indian vote dilution cases are unique or are somehow an exception to the Voting Rights Act are unavailing.

In Windy Boy v. County of Big Horn, ${ }^{154}$ the Montana federal district court rejected the tribal sovereignty/reduced participation position. In Windy Boy, the court considered the issue of dual status and whether it reduced Indian political participation. The court stated:

The Court does not find that dual sovereignty explains the inability of Indians to participate fully in the political processes of $\mathrm{Big}$ Horn County. Indians, for example, as concerned about schools as white citizens, and a good number have run for school board over the last twenty years. There is no evidence that interest in tribal affairs has not in any lessened Indian parents' involvement in their children's education. Racially polarized voting and the effects of past and present discrimination explain the lack of Indian political influence in the country, far better than existence of tribal government. ${ }^{15 s}$

The tribal sovereignty/reduced participation position has also been equated to the arguments made by southerners to justify black disenfranchisement and white supremacy-that is, that black-white relations were special or unique, that blacks preferred segregation, that they wanted to be separate from whites, that they did not want to register and vote, and that they

150. Id. at 24.

1S1. 42 U.S.C. $\$ \S 1973$ c, 1973b, 1973aa-1a (1976); 28 C.F.R. $\$ 55$ app. (1984).

152. Pub. L. No. 97-205, §2, 96 Stat. $131,131-32$ (codified at 42 U.S.C. $\S 1973($ a) (1973)).

153. S. Rep. No. 417, 97th Cong., 2d Sess. 27, 42 (1982).

154. 647 F. Supp. 1002 (D. Mont. 1986).

155. Id. at 1021 . 
preferred their own way of doing things. ${ }^{156}$ Like many generations of southerners who defended segregation, the states seek to blame the victim for the crime.

Finally, the argument that Indians have less political energy than whites to exert on state or county elections because their time is spent exclusively on tribal matters is a variant of the "apathy" argument which has been used to justify the exclusion of blacks from political participation in the South-an argument uniformly rejected by the courts. ${ }^{157}$ States would be hard-pressed to demonstrate a case that Indians have less political energy than whites. History shows Indians have, in fact, participated and are willing to participate when given the opportunity. Indeed, studies of Indian voters in the states of Montana, South Dakota, Washington, Arizona, and New Mexico demonstrate that issues of concern to Indian voters can impact the outcome of state and local elections. 158

\section{The Continuing Quest for Full Political Participation}

The majority of blatant legislation and local actions which prohibit Indians from voting have been repealed or struck down by the courts. Registration of Indian voters has increased substantially, resulting in a dramatic increase in the number of

156. This argument was presented by the plaintiffs in Windy Boy. Plaintiff's Response to Defendants' Post-Trial Brief at 9, Windy Boy (No. DV 83-225-BLG). See also Derfner, Racial Discrimination and the Right to Vote, 26 VAND. L. Rev. 523 (1973) (discussion of the disenfranchisement of blacks after Reconstruction).

157. United States v. Marengo County Comm'n, 731 F.2d 1546, 1568 (11th Cir. 1984); United States v. Dallas County Comm'n, 739 F.2d 1529, 1536 (11th Cir. 1984); Kirksey v. Board of Supervisors, 554 F.2d 134, 145 (5th Cir. 1977).

158. A recent political behavior study at the Tohono O'dham and Gila River Reservations in Arizona concluded that a candidates' stand on Indian issues and concerns for Indians were very important, receiving high percentages of $81 \%$ and $86 \%$ respectively. Nat'l Indian Youth Counce, Political and attitudes Behavior Poll at Tohono O'odham ANd Gina Rrver, Aruzona (1986). Similarly, a poll conducted on the Navajo Reservation showed that $69 \%$ of Navajos interviewed found a candidate's concern for Indian issues and people the most important factor. NaT'L INDIAN Youth Counch, Navajo indian Political Atrmtudes and Behavior Poll 16 (1984).

Helen Peterson examined Indian voters in the 1952 and 1956 elections and found Indians turning out to vote against specific policies affecting Indians. Peterson, supra note 74, at 125. Stephen Kunitz's and Jerrold Levy's study of Navajo voting in the 1968 national election and Jack Holmes' review of Navajo voters in the 1967 New Mexico election showed Navajos voting on issues of importance to them and supporting specific candidates sponsoring such issues. Kunitz \& Levy, Navajo Voting Patterns, Platenu, Summer, 1970, at 1, 1-8; J. Holmes, Politics in New Mexico (1967). See also D. McCoos, supra note 91 , at $116-28$. 
Indians voting. ${ }^{139}$ Indians are seeking election to local school boards and state government positions. Grassroots coalitions and groups formed in Indian communities are registering Indian voters door-to-door, sponsoring candidate forums, and providing voter information on significant issues. The result is a greater awareness among Indians of their voting rights and the significant influence they can have on local, state and county elections.

In 1986, a National Indian Youth Council report showed there were 852 Indians holding a nontribal elected office. Of the officeholders, more than $90 \%$ were serving on school boards, 49 were serving in state-level positions, and one served in Congress. ${ }^{160}$

A consequence of this upsurge in Indian political action and success in the election of Indian candidates is a marked increase in voting rights litigation. Indians are challenging state-devised election schemes and systems that submerge Indian voting strength or deny equal and effective participation in the political process. The primary tool utilized by Indian voters to assert and protect their fundamental constitutional rights is the Voting Rights Act of $1965 .{ }^{161}$

The Voting Rights Act of 1965 is the culmination of efforts to create an effective remedy for the systematic discriminatory voting practices against minority communities. The Act is aimed at precluding state government officials from interfering with the right of minorities to register and vote. It is a complex compilation of general provisions that are permanent and affect all states and specific provisions that are temporary and only affect jurisdictions that meet particular criteria stipulated in the Act. ${ }^{162}$

The most important provisions of the Act are section 2, which bans voting practices that result in the denial or abridgment of the right to vote on account of race, color, or membership in

159. See Windy Boy, 647 F. Supp. at 1004, 1007; D. McCool, supra note 91, at 119-20. Despite this undeniable progress, registration and turnout of Indian voters can still be characterized as low, as with other minority voters.

160. Nat'l Indlan Youth Counch, Indun Elected Offichals Directory (Nov. 1986). The sole congressman is Ben Nighthorse Campbell, a Northern Cheyenne residing in Colorado.

161. Pub. L. No. 89-110, 79 Stat. 437 (codified as amended at 42 U.S.C. $\$ \S 1971$, 1973-1973bb-1 (1982)).

162. Provisions of the Voting Rights Act are described in U.S. Comm'N ON CrvI Rights, The Voting Rights ACt: Unfurfmled Gonls 4-21 (1981) thereinafter UnfulFILLED GOALS]. 
a language minority, ${ }^{163}$ and sections 4 and 201, which abolish "tests and devices" for voting. ${ }^{164}$ In 1970, Congress extended the ban for five years and made it applicable nationwide. ${ }^{165}$ Five years later, Congress made the ban permanent. 166 In 1982, Congress amended section 2 by adopting the results standard, primarily in response to City of Mobile $v$. Bolden. ${ }^{167}$

Other permanent provisions of the Act make it a crime to deprive or intend to deprive anyone of the rights protected by the Act, ${ }^{168}$ abolish durational residency requirements, and establish uniform standards for absentee voting during presidential elections. ${ }^{169}$ Additionally, the Act provides that any voter who needs assistance because of a disability or an inability to read or write is entitled to assistance. ${ }^{170}$

163. In 1982, Congress strengthened the protection of the Act by amending $\S 2$. See Voting Rights Act of 1982, Pub. L. No. 97-205, § 2, 96 Stat. 131, 131-32 (codified at 42 U.S.C. $\$ 1973$ (a) (1973)). Amended $\$ 2$ provides:

No voting qualification or prerequisite to voting or standard, practice, or procedure shall be imposed or applied by any state or political subdivision in a manner which results in a denial or abridgement of the right of any citizen of the United States to vote on account of race, color or in contravention of the guarantees set forth in section 1973 (f) (2) of this title as provided in subsection (b) of this section.

164. 42 U.S.C. $\$ 1973 b$ (1976). Congress did not outright ban the use of the poll tax as a condition for registration but did determine that the tax "denied or abridged" the right to vote. Congress authorized the United States Attorney General to bring suit in any jurisdiction where the tax was used to enjoin its enforcement. Id. $\$ 1973 \mathrm{~h}$.

165. Voting Rights Act Amendments of 1970, Pub. L. No. 91-285, 84 Stat. 314. The Act had previously applied to specific jurisdictions.

166. Act of Aug. 6, 1975, Pub. L. No. 94-73, 89 Stat. 402.

167. 446 U.S. 55 (1980). In 1980, a sharply divided Court established a subjective intent standard for vote dilution claims under the Constitution and $\$ 2$ of the Act. The plurality held that proof of racial purpose was a prerequisite for a violation of voting rights. Id. at 72-74. For a discussion of the standard in vote dilution cases applied by the courts pre-Bolden, see Parker, The "Results" Test of Section 2 of the Voting Rights Act: Abandoning the Intent Standard, 69 VA. L. REV. 715 (1983).

168. 42 U.S.C. $\$ 1973 \mathrm{j}$ (1976).

169. Id. \& 1973aa-1.

170. Voting Rights Act, Amendments of 1982, Pub. L. No. 97-205, $\$ 5$, 96 Stat. $131,134-35$ (codified at 42 U.S.C. $\$ \$ 1973 \mathrm{aa}-6$ (1983)). Another provision of the Act allows the Attorney General to send federal examiners to covered jurisdictions when the Attorney General has received twenty or more written complaints alleging voter discrimination in that jurisdiction. 42 U.S.C. $\$ \$ 1933 d, 1933 f$ (1976).

Under $\$ \$ 3(a)$ and $3(c)$ of the Voting Rights Act, a federal court can order a jurisdiction to pre-clear [obtain approval] of its upcoming election. The federal court can then authorize the appointment of federal examiners if the Attorney General or an aggrieved person files suit to enforce the voting guarantees of the fourteenth and fifteenth amendments. 42 U.S.C. $\S 1973 a(a)$ (1976). Under $\& 5$ of the Act, certain jurisdictions 


\section{Bilingual Elections}

A special provision of the Act requiring assistance to language minorities (American Indians, Asian-Americans, Alaska Natives and Hispanics) was added in $1975 .{ }^{171}$ This provision was recently extended until 1992. ${ }^{172}$ In 1975, Congress determined that "voting discrimination against citizens of language minorities is pervasive and national in scope." ${ }^{173}$ It further concluded that, based on testimony, language minorities had "been denied equal educational opportunities by state and local governments" causing them to have "severe disability and continuing illiteracy" in English. ${ }^{174}$ Language barriers combined with English-only registration and voting procedures excluded language minorities from effective political participation. These were excellent reasons for congressional passage of the special minority language provisions.

are encompassed by the Act and, therefore, are required to submit proposed changes in its voting laws, practices, or procedures to either the U.S. Attorney General or the U.S. District Court for the District of Columbia. See 42 U.S.C. $\& 1973$ c (1982 \& Supp. IV 1986).

Federal examiners have been appointed in two jurisdictions affecting Indians in situations not covered under the section. In United States $v$. Thurston County, Nebraska, No. 78-0-380 (D. Neb. May 9, 1979) (consent decree), pre-clearance was stipulated in a consent decree between the County and the Attorney General. The Attorney General challenged the County's at-large method of electing its board of supervisors. It argued that this method diluted the voting rights of members of the Omaha and Winnebago Tribes, in violation of 82 of the Voting Rights Act. The consent decree required county commissioners to be elected from single member districts. In addition, Thurston County was placed under \&3(a), federal examiners were appointed, and the jurisdiction was required to pre-clear its election changes for 5 years. Id. at 3.

The second case, United States v. Town of Bartelme, No. 78-C-101 (E.D. Wis. Feb. 17, 1978), involved Indian residents of the Stockbridge-Munsee Reservation in Wisconsin. The United States alleged the Bartelme and Shawano County, Wisconsin, denied residents of the Stockbridge-Munsee Reservation the right to vote. Town residents had signed a petition that would sever the Reservation from the town. The petition was approved by the County. Thus, residents of the Reservation were no longer allowed to vote in city or county elections. However, a preliminary injunction was issued ordering the town to allow residents of the Stockbridge-Munsee Reservation to vote.

171. Voting Rights Act, Amendments of 1975, Pub. L. No. 94-73, $\S 207,89$ Stat. 401, 402 (codified at 42 U.S.C. $\$ 19731(\mathrm{c})(3)$ (1982)) (amending $\$ 14(\mathrm{c})(3)$ of the Act).

172. See Pub. L. No. 97-205, $\$ 4,96$ Stat. 131, 134 (codified at 42 U.S.C. $\S \S$ 1973aa-1a (1982)).

173. Voting Rights Act, 1975 Amendments, Pub. L. No. 94-73, $\S 203,89$ Stat. at 401 (codified at 42 U.S.C. $\$ 1973 \mathrm{~b}(\mathrm{f})(1)(1982)$ ) (amending $\S 4(\mathrm{f})(1)$ of the Act).

174. See Extension of the Voting Rights Act of 1965: Hearing on S.407, S.903, S.1297, S.1409 and S.1443, Before the Subcomm. on Constitutional Rights of the Senate Comm. on the Judiciary, 94th Cong., 1st Sess. 214-19, 255-68, 738-56, 756-89 (1975). 
Specific jurisdictions under this section are required to provide bilingual forms and notices, bilingual ballots, bilingual voter information, and oral assistance at the polls. ${ }^{175}$ The provisions also provide that when the language of the minority is oral or unwritten, as many Indian languages are, the specific jurisdiction" is "only required to furnish oral instructions, assistance, or other information relating to registration and voting." 17

Two Navajo cases, Apache County High School Dist. No. 90 $v$. United States ${ }^{178}$ and United States $v$. County of San Juan, New Mexico, ${ }^{179}$ are illustrative of the types of problems that arise with the bilingual requirements. ${ }^{180}$ In 1975, the Apache County High School District in Arizona brought a declaratory judgment in the United States District Court for the District of Columbia in order to pre-clear its bilingual plan for a bond election. In Apache County High School Dist. No. 90 v. United States, the district court denied the school district's request and found it had "deliberately failed to inform the Navajos" about the election issues and the issues, because it had not disseminated information in the Navajo language and it had not sent information to Navajo chapter officials. ${ }^{181}$ Further, the court found the school district had not provided bilingual Navajo poll workers and it had limited the number of polls on the Navajo Reservation. ${ }^{182}$

A second, similar suit was brought five years later. In United States v. County of San Juan, New Mexico, the United States alleged that San Juan County failed to provide "oral instructions, assistance, and other information relating to the registration and voting process in the Navajo language whenever such language was provided in English"; equate number of bilingual Navajo interpreters; ${ }^{184}$ and failed to

175. 42 U.S.C. $\$ \$ 1973(b)(f)(3), 1973 \mathrm{aa}-1 \mathrm{a}(\mathrm{b})$, (c) (1982); 28 C.F.R. $\$ 55.19$ (1980).

176. See 28 C.F.R. $\$ 51$ appendix (1988) for jurisdictions covered under $\$ 5$ and the minority language provisions.

177. 42 U.S.C. \$§ 1973(f)(4), 1973aa-1a(c) (1976).

178. No. 77-1815 (D.D.C. June 12, 1980).

179. No. 79-508JB (D.N.M. April 8, 1980).

180. These two cases are discussed extensively by the U.S. Commission on Civi Rights in UNFurfILlED GoALs, supra note 169, at 87-88.

181. Apache County High School, No. 77-1815, slip. op. at 4.

182. Id. at 5-6.

183. Complaint at 4, United States v. County of San Juan, New Mexico (No. 79. 508JB).

184. Id. 
provide sufficient information (in the Navajo language) concerning locations of polling places. 185

The parties entered into a settlement in which San Juan County agreed to comply with the minority language provisions in preparing and conducting elections. ${ }^{186}$ In addition, the County agreed to (1) train poll workers in aspects of voter registration and in giving assistance to bilingual voters; (2) establish more poll places on the Navajo Reservation; (3) publish voting information in Navajo and English; and (4) undertake a voter registration of Navajos. ${ }^{187}$

\section{Section 2 of the Voting Rights Act}

In 1982, Congress amended the Voting Rights Act. ${ }^{188}$ The amendments to section 2 received the great debate because the requirement of proving a discriminatory purpose for a section 2 violation was eliminated. ${ }^{189}$ Amended section 2 provides that any voting law or practice which "results" in discrimination on account of race or color, or language minority status, is unlawful. ${ }^{190}$

In Bolden, the Supreme Court stated that proof of a discriminatory purpose was required to establish a statutory violation of section $2 .{ }^{191}$ Congress responded directly to Bolden by amending the Voting Rights Act. The report of the House Committee on the Judiciary explained the purpose of the amendment was "to make clear that proof of discriminatory purpose or intent is not required in cases brought under that provision" and "to restate Congress' earlier intent that violations of the Voting Rights Act, including section 2, could be established by showing the discriminatory effect of the challenged practice," 192 and the dilution or diminishment of the voting strength of minority voters. Both the House and Senate reports give detailed guide-

185. Id.

186. Id. For minority language provisions, see 25 U.S.C. $\$ 1973 \mathrm{aa}-1 \mathrm{a}(1982)$.

187. United States v. County of San Juan County, Utah, No. 79-508JB, stipulation at 4.

188. Pub. L. No. 97-205, 96 Stat. 131 (codified at 42 U.S.C. $\$ 1971-1975$ (1982)). 189. Id. at 134. See Parker, The Results Test of Section 2 of The Voting Rights Act: Abandoning the Intent Standard, 69 VA. L. REV. 715 (1983) (discussion of the amendments to \& 2).

190. Pub. L. No. 97-205, § 2, 96 Stat. 131, 131-32 (codified at 42 U.S.C. $\$ \S 1973$ (a) (1982)).

191. City of Mobile v. Bolden, 446 U.S. 55, 60-74 (plurality opinion)

192. H.R. No. 227, 97th Cong., 1st Sess. 29 (1981). 
lines on the implementation of section 2 and congressional intent in amending the Act. ${ }^{193}$

Vote dilution is "a process whereby election laws or practices, either singly or in concert, combine with systematic bloc voting among an identifiable group to diminish the voting strength of at least one other group." 194 Vote dilution takes many forms, including reapportionment plans that fragment or concentrate populations, ${ }^{195}$ staggered terms, ${ }^{196}$ majority vote requirements, ${ }^{197}$ annexations, ${ }^{198}$ and numbered posts. ${ }^{199}$ The predominant form of vote dilution today is at-large voting or multi-member districting.

Under an at-large scheme, residents of a school district or county vote for the membership of the school board or county commission. The majority, if it votes as a bloc, can choose all the board members or officials, thus denying the minority an effective opportunity to elect representatives of its choice. These election systems can and do negate the gains made by minority voters under the Voting Rights Act.

The amendment to section 2 and the subsequent Supreme Court decisions ${ }^{200}$ have greatly supported Indian vote dilution claims. Most of the litigation has been initiated or supported by the Native American Rights Fund, National Indian Youth Council, the Legal Services Corporation, and the American Civil Liberties Union.

193. S. REP. No. 417,97 th Cong., 2 d Sess. $27,28-9$ (1982). These factors are taken from the pre-Bolden voting cases of White v. Regester, 412 U.S. 755 (1973); Zimmer v. McKeithen, 485 F.2d 1297 (5th Cir. 1973) (en banc), aff'd on other grounds sub nom. East Carroll Parish School Bd. v. Marshall, 424 U.S. 636 (1976).

194. C. Davidson, MnNorrty Vote Dinution 4 (1984). The basic voting dilution principles derive from the one person-one vote reapportionment case of Reynolds $v$. Sims, 377 U.S. 533 (1964). There, the Supreme Court stated:

There is more to the right to vote than the right to mark a piece of paper and drop it in a box or the right to pull a lever in a voting booth. The right to vote includes the right to have the ballot counted. ... It also includes the right to have the vote counted at full value without dilution or discount ... that federally protected right suffers substantial dilution ... [ [where a] favored group has full voting strength . . . [and] [t]he groups not in favor have their voters discounted.

Id. at 555 n.29 (quoting South v. Peters, 339 U.S. 276, 279 (1950) (Douglas, J., dissenting)).

195. See Windy Boy v. County of Big Horn, 647 F. Supp. 1002 (D. Mont. 1986).

196. See City of Rome v. United States, 446 U.S. 156 (1980).

197. See City of Port Arthur v. United States, 459 U.S. 159, 167 (1982).

198. See id. at 166-67.

199. See Rogers v. Lodge, 458 U.S. 613, 627 (1982).

200. See id.; Thornburg v. Gingles, 478 U.S. 30 (1986). 
In 1986, in Windy Boy, the federal district court in Montana alleged the Big Horn County and School District's at-large election schemes were violative of section 2. Windy Boy came about as a years of unsuccessful attempts by Crow and Northern Cheyenne individuals to elect an Indian to the county commission and to the school board. The Indian plaintiffs presented extensive evidence of past and continuing discrimination or polarization in voting, public accommodations, employment, appointments to boards and commissions, police protection, political associations, housing, social and business organizations, and churches. Historians, political scientists, and statisticians, serving as expert witnesses on behalf of the plaintiffs, recounted the record of discrimination in Big Horn County. ${ }^{201}$ The court decided overwhelmingly in favor of the plaintiffs and ordered the county and school district be redistricted into single-member districts. ${ }^{202}$

The use of single-member districts is an effective remedy to voter dilution in at-large voting schemes. Single-member districts have been utilized in several claims against at-large voting in New Mexico, ${ }^{203}$ Arizona, ${ }^{204}$ and Colorado. ${ }^{205}$

Where the minority population is geographically dispersed, single-member districts do not always provide an equal opportunity for minorities to elect representatives of their choice. ${ }^{206}$ Limited and cumulative voting schemes are alternatives. In a cumulative system, a voter casts a multiple vote for less than a

201. Windy Boy, 647 F. Supp. at 1006 . In racial vote dilution cases, the courts have utilized several standards to demonstrate vote dilution. In Windy Boy, the court relied on the factors developed in Zimmer v. McKeithen, 485 F.2d 1297 (5th Cir. 1973).

202. Windy Boy, 647 F. Supp. at 1023 . A single member district is where members of the minority group constitute a majority.

203. Tso v. Cuba Indep. School Dist., No. 85-1023-JB (May 18, 1987) (consent decree); Largo v. McKinley Consol. School Dist., No. 84-1751 HB (Nov. 26, 1984); Estevan v. Grants-Cibola County School Dist., No. 84-1752 HB (Nov. 26, 1984). In March 1985, the New Mexico legislature ended at-large voting schemes for all county commissions, except in counties with populations less than 2,000, and for all school boards, except districts with fewer than 500 students. See also Casuse v. City of Gallup, No. 88-1007-HB (D.N.M. 1988). Bowannie v. Bernalillo School Dist., No. CN88-0212 (D.N.M. 1988).

204. Clark v. Holbrook Pub. School Dist., No. 3, No. 88-0148 PCTRGS (D. Ariz. 1988).

205. Cuthair v. Montezuma-Cortez, Colo. School Dist. No. RE-1, No. 89-C-964 (D. Colo. 1990) (consent decree).

206. See Criteria for Districting: A Social Science Perspective, 33 UCLA L. REv. 77, 160 (1985); Note, Alternative Voting Systems As Remedies for Unlawful At-Large Systems, 92 Yale L.J. 144 (1982); Still, Alternatives to Single-Member Districts, in MnNorty Vote Dilution, supra note 194, at 249-67. 
full slate of candidates (i.e., a voter casts more than one vote). ${ }^{207}$ A voter does not have to belong to a plurality or a majority of the electorate in order to elect a candidate of his choice. $\mathrm{Cu}$ mulative voting has recently been used during settlements of minority vote dilution cases in Alamagordo, New Mexico; Peoria, Illinois; and several towns in Alabama.

The cumulative voting system has been adopted in a recent South Dakota case. In Buckanaga v. Sisseton School District, ${ }^{208}$ members of the Sisseton Wahpeton Sioux Tribe challenged the at-large voting system. In 1980, the Sisseton School District contained 5,628 residents, of which $33.9 \%$ were Indian. ${ }^{209}$ The school district was governed by a nine member board; three of the nine members were elected every year to three year terms. ${ }^{210}$ Tribal members had consistently been candidates for seats on the school board, but had rarely been successful. ${ }^{211}$

On remand, the parties entered into a consent decree, agreeing to the use of cumulative voting rules in future elections. ${ }^{212}$ Voters acquired the option of casting their three votes in any combination they wished. This allowed the school district to retain its at-large, staggered-term system, yet provided the tribal members with a more realistic opportunity to elect a candidate of their choice.

The first interim election under the new voting rules was held in June, 1989, and resulted in an Indian winning over a field of seven candidates. In the May, 1990, election, a full ninemember board was elected by the school district voters. Three Indians were elected to the board. ${ }^{213}$

Other discriminatory election laws and practices have fallen when challenged by Indian voters. ${ }^{214}$ In a South Dakota case, a few days prior to the November, 1984, general election, a county auditor rejected registration cards from an Indian registration

207. See Note, supra note 213 , at $148-49,153-54$.

208. No. 84-1025 (D.S.D. 1985) (1985 WL 6683), rev'd and remanded, 804 F.2d 469 (8th Cir. 1986).

209. Id., 804 F.2d at at 470.

210. Id.

211. Id., 804 F.2d at 476. The record showed that "from 1974 to the present [1986], there has been only one Indian board member; and since 1982, 23 Indians sought office and only 3 were successful." Id.

212. Consent Decree, Buckanaga v. Sisseton Indep. School Dist., No. 84-1025 (1988).

213. Report from Harvey DuMarce to the Native American Rights Fund (May, 1990) (unpublished report).

214. See, e.g., Love v. Lumberton City Bd. of Educ., No. 87-105-CIV-3 (D.N.C. 1987) (Lumbee Indians successfully challenged multi-member districting in North Carolina). 
drive. ${ }^{215}$ One day before the general election, the district court ordered the county officials to permit the Indians to vote. ${ }^{216}$

In addition, Indians conducting registration drives have been impeded by county officials. For example, a county auditor limited the number of application forms to be given to Indian voter registrars to ten-to-fifteen apiece. The registrars had traveled approximately eighty miles round-trip to begin their registration drive. In Fiddler $v$. Sisker, ${ }^{217}$ the court held the county auditor had discriminated against Indian voters in violation of section 2 . The court extended the deadline for voter registration by one week. ${ }^{218}$

In addition to the situations of Fiddler and American Horse, Indian voters have challenged the denial of polling places in outlying Indian communities. In Black Bull v. Dupree School District No. 64-2, ${ }^{219}$ the Dupree School District was ordered to establish four polling places on the Cheyenne River Sioux Reservation. Prior to the lawsuit, Indian voters were forced to travel up to 150 miles round-trip to vote in school board elections. ${ }^{220}$

Indian voters have also been involved in reapportionment lawsuits. In Sanchez v. King, ${ }^{221}$ New Mexico's reapportionment plan was found to be violative of the one-person one-vote principle. In Sanchez, the defendants were ordered to redraw districts in compliance with the principle of population equality. After the state legislature redrew the districts, Indian and Hispanic voters, in a second phase of the case, attacked the districting scheme on the grounds that the scheme resulted in an impermissible dilution of minority voting strength violative of section 2. A court-imposed redistricting plan was ordered into effect to bring the state into compliance. 222

In summary, the above cases have demonstrated that as recently as eight years ago, Indian voters were covertly discrimi-

215. American Horse v. Kundert, No. 84-5159 (D.S.D. Nov. 5, 1984).

216. Id., slip op. at 1 (Order).

217. No. 85-3050 (D.S.D. Oct. 24, 1986). Similar evidence of discrimination was presented in Windy Boy. See supra notes 201-02 and accompanying text.

218. Fiddler, No. 85-3050.

219. No. 86-3012 (D.S.D. May 14, 1986) (Stipulation for Settlement).

220. Prior to the stipulation, a temporary restraining order was ordered to halt the school board election.

221. 550 F. Supp. 13 (D.N.M. 1982), aff'd 459 U.S. 801 (1983). See also Ratcliff v. Municipality of Anchorage, No. A86-036 (D. Alaska 1989) (challenge to reapportionment plan of city by Alaskan Natives).

222. Sanchez v. King, No. 82-0067-M (Aug. 8, 1984). 
nated against, and were required to seek adjudication of a right long recognized as a personal right.

\section{Conclusion}

This article has discussed the resistance by states and local entities to Indian participation in virtually every aspect of the electoral process. While early federal policies encouraged Indians to adopt the ways and practices of the majority society, Indians were prohibited from exercising their freedom of choice of representatives. The courts have played a major role in construing the numerous, and sometimes conflicting, federal statutes and regulations that seek to protect Indian voting rights, and will continue to do so in the future.

With the passage of the Voting Rights Act of 1965, Indians have intensified the fight for increased political participation and have made great strides in defeating the various discriminatory state voting schemes. Indians will continue to face the enduring legacy of racial discrimination as the campaign for equal voting rights spreads throughout Indian Country. Indians now know they can significantly influence the local political decision-making policies that affect their lives. Thus, Indians will continue to seek the goal of political equality envisioned in the fifteenth amendment and the Voting Rights Act of 1965. 